\title{
進行胃癌への合併摘脾と免疫療法
}

岡山大学医学部第 1 外科

\begin{tabular}{|c|c|c|c|}
\hline 棆 & 昭 & 島 啓 & 明 \\
\hline
\end{tabular}

\section{COMBINED SPLENECTOMY AND IMMUNOTHERAPY FOR ADVANCED GASTRIC CANCER}

\author{
Hiroaki MIWA, Keimei KOJIMA, Kiyoshi HIROSE, Akira MATSUMI, \\ Minoru MORIYAMA and Kunzo ORITA
}

The 1st Department of Surgery, Okayama, University Medical School

上中部進行胃癌 stage III, IV例に摘脾を併用し細胞性免疫能と予後をみた。摘脾は stage III胃癌にはむしろ逆効果だったが stage IV胃癌に延命をもたらした，摘脾と免疫 療法についてみると, 摘脾群では免疫療法の有無で生存率に差がなかったが, 非摘脾群 では stage IIIで免度療法例に, stage IVで非免疫療法例に延命がみられた。細胞性免疫 能は生存率をよく反映した。

I 、はじめに

癌患者の治療成績向上のためには，多くの治療法を 駆使した集学的治療が必要であろ5。胃癌患者に対し ては，現時点では手術が最も頼れる治療法であり，化 学㞠法, 免疫療法子活用され, 加えて栄養の問題も上 記の治療を充分に駆使する上で重要であろら.危疫療 法はまだ新しい治療法であり, 癌患者に抗腫瘍効果を 与え，延命に導く成績も多くみられているが，その主 体は現時点では免疫賦活剂を用いる非特異的免疫療法 であり，われわれるその成果について報告してきてい る1”。一方, 担癌生体における脾葴はある時期には免疫 抑制的に働くと考えられ，その時期での摘脾は抗腫瘍 彻果をるたらそう，われわれはすでに担癌マウスの早 期の摘脾や，前期胃癌例での手術時の摘脾が抗腫瘍効 果や延命をむたらすことを報告してきだ23). 今回進行 胃癌 stage III, IV 例への合併摘脾（摘脾）の効果を非 特異的免疫療法との併用の有無より検討し，興味ある 結果を得たので報告する。

\section{II. 研究对象书よU゚方法}

対魚：岡大第一外科に入院し胃全摘出術をらけた上 中部胃癌で，手術時に脾葴摘出を併用した摘脾群は70 例，非摘脾群は49例であり， stage III")例では免疫療法
を行わなかった例が 2 ～倍と多かったか， stage IV では免疫療法施行例と非施行例の例数がほほ同じで あった（表 1).

方法：免疫療法としては免疫賦活剂である levamisole (LMS) を用い, 手術 3 日前より1 日150mg を連 続 3 日間，隔週毎と可能なかぎり長期に亘って投与し た. 化学療法は主として mitomycin C, FT-207の MF 療法を用いた。

細胞性免度能としては末梢血リンバ球数, 末梢血り ンハ球の PHA に対する幼若化率6)，PPD 皮底反应”, PHA 皮痛反心店を用いた。

\section{III. 桔 果}

\section{No. 10, No. 11 ヘのリンパ亩転移率}

上中部胃癌 stage III, IV 胃全摘例の No. 10 リンバ節 への転移率は非摘脾群で5.6\%であるのに対し, 摘脾群 では32.5\%と压倒的に高率であった．No.11へのリン ハ節転移率は前者で $41.7 \%$ であり，後者では $33.3 \%$ 之 前者でやや高かった．全体的には摘脾群にはリンバ節 転移が多く，そのために摘脾したといえる（図 1).

\section{2. 細胞性免疫能に与える効果}

stage III, IV胃癌全体の細胞性免疫能の変動を手術 前と術後 1 カ月で,リン八球 PHA 幼若化率, リンハ・球 
表 1 研究対象

\begin{tabular}{lcccccccc} 
& & & \multicolumn{3}{c}{ (Jan. 1965 Dec. 1980) } \\
\hline $\begin{array}{l}\text { Upper } \\
\text { and } \\
\text { middle } \\
\text { gastric } \\
\text { cancer }\end{array}$ & \multicolumn{2}{c}{$\begin{array}{l}\text { With splenectomy } \\
\text { Immuno- } \\
\text { chemotherapy }\end{array}$} & \multicolumn{3}{c}{$\begin{array}{l}\text { Without splenectomy } \\
\text { Immino- } \\
\text { chemotherapy }\end{array}$} \\
\hline stage III & 16 & 28 & 44 & 10 & 28 & 38 \\
stage IV & 13 & 13 & 26 & 5 & 6 & 11 \\
Total & 29 & 41 & 70 & 15 & 34 & 49 \\
\hline
\end{tabular}

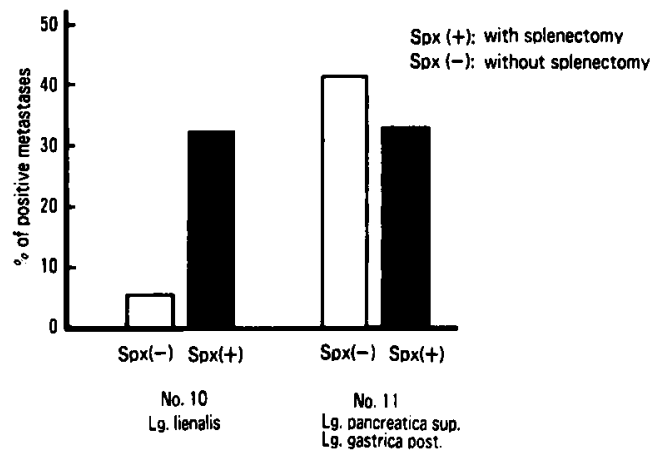

図 1 No. 10,No. 11 リンパ節転移陽性率

数，PPD 皮席反応，PHA 皮届反応でみた。

リンパ球 PHA 幼若化率は非摘脾群で手術前が $36.6 \pm 12.6 \%$, 術後 1 力月で $45.2 \pm 11.5 \%$, 摘脾群で 前者か3 $37.7 \pm 12.7 \%$, 後者が $43.1 \pm 11.5 \%$ と両群とも に術後にやや上昇した。リンハ球数は非摘脾群で前が $3055 \pm 1422 / \mathrm{mm}^{3}$, 後が2033 $\pm 746 / \mathrm{mm}^{3}$ と下降したが,

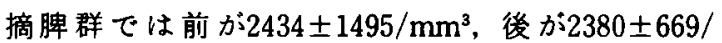
$\mathrm{mm}^{3}$ と変動がなかった. PPD 皮成反応は非摘脾群で前 が16.7 $\pm 12.1 \mathrm{~mm}$, 後が $13.2 \pm 11.1 \mathrm{~mm}$, 摘脾群では前 か $26.1 \pm 18.2 \mathrm{~mm}$, 後か $18.2 \pm 22.4 \mathrm{~mm}$ と共に軽度低 下した。 また PHA 皮層反応は非摘脾群で前が $45.0 \pm$ $5.0 \mathrm{~mm}$, 後が $34.7 \pm 11.5 \mathrm{~mm}$, 摘脾群で前が $43.7 \pm 23.1$

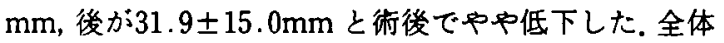
的に細胞性免疫反応の術前後の変動は摘脾の有無で变 わらなかった（図 2).

stage IV 胃癌だけについてみると,リンハ球 PHA 幼若化率は非摘脾群で前が $38.9 \pm 12.1 \%$ ，後が $46.6 \pm$ $5.0 \%$ ，摘脾群で前が $35.5 \pm 3.7 \%$ ，後が $43.3 \pm 14.0 \%$ と共にやや上昇、リンバ球数は非摘脾群で前が $3136 \pm$ $1678 / \mathrm{mm}^{3}$, 後が2090 $1017 / \mathrm{mm}^{3}$, 摘脾群で前が $2135 \pm 1027 / \mathrm{mm}^{3}$, 後が2222 $\pm 680 / \mathrm{mm}^{3}$ と非摘脾群で 術後に低下した。また，PPD 皮庯反応は非摘脾群で前
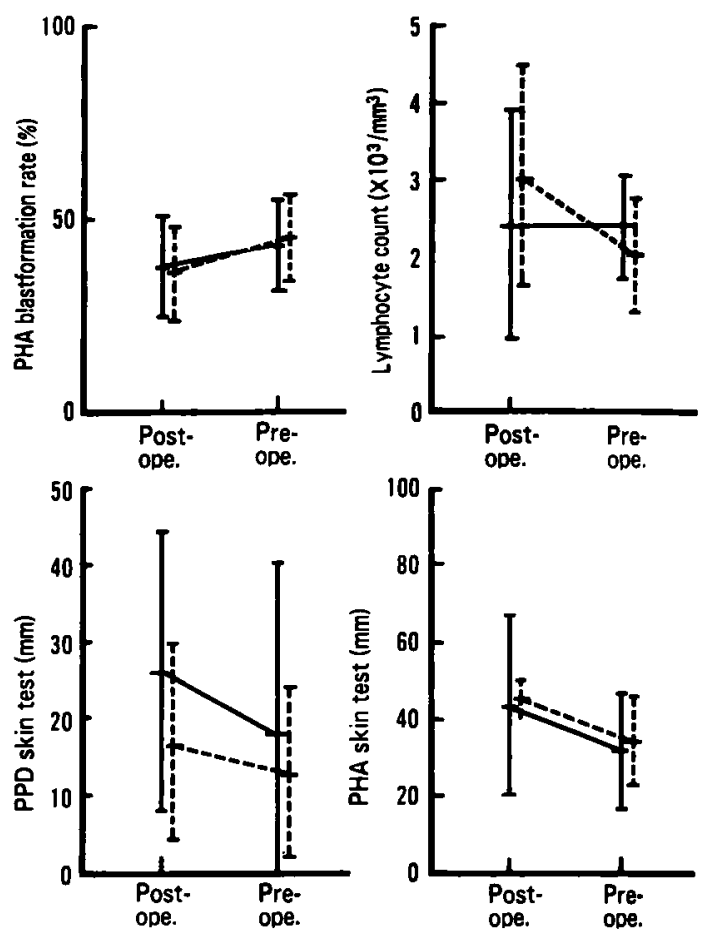

—: with splenectomy, $\cdots$; without splenectomy

図 2 stage III，IV胃嵒例の手術前後の梱胞性免疫能 の变動

が13.7士17.6mm, 後が $10.0 \pm 20.3 \mathrm{~mm}$ 之摘脾群で上 昇した. stage IV胃癌全体では, 摘脾群の細胞性免度反 応は術後に上昇する傾向にあった（图了）。

\section{3. stage III胃癌例の生存率}

stage III胃癌例の生存率を非摘脾群と摘脾群で術後 4 年までみた，非摘脾群38例の $1 ， 2 ， 3 ， 4$ 年生存 率は各 $81.6 \%, 51.2 \% ， 35.7 \% ， 28.9 \%$ であり，摘脾 群でのそれは各65.0\%，43.8\%，30.3\%，26.3\%と後 者で低值を示した（図4）.

stage III胃癌例を摘脾の有無の上に更に免疫療法の 有無で分けて各々の生存率を比较検討した，まず非啇 脾群について，免疫療法非併用例，併用例の同しく擜 後 4 年までの生存率をみると，前者では各 $78.6 \%$ ， $47.2 \%, 28.3 \%, 28.3 \%$ ありり, 後者では90.0\%, $66.6 \% ， 66.6 \% ， 66.6 \%$ と，摘脾をしない時は免度度 法が生存率を高めた。次いで摘脾群について同様に模 討した結果では，非免疫療法例では各70.4\%，40.6\%。 $29.0 \%, 24.2 \%$, 免疫療法例では各 $53.8 \% ， 38.4 \%$, $38.4 \% ， 38.4 \%$ と，摘脾をした時には免疫療法の有無 で差がなかった（図 5 )。 

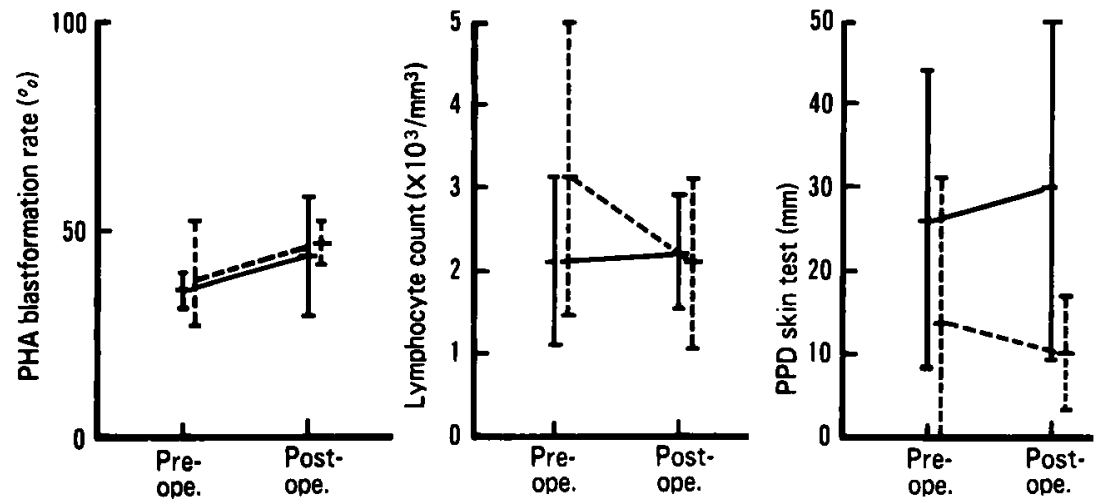

—: with splenectomy, …..: without splenectomy

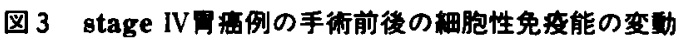

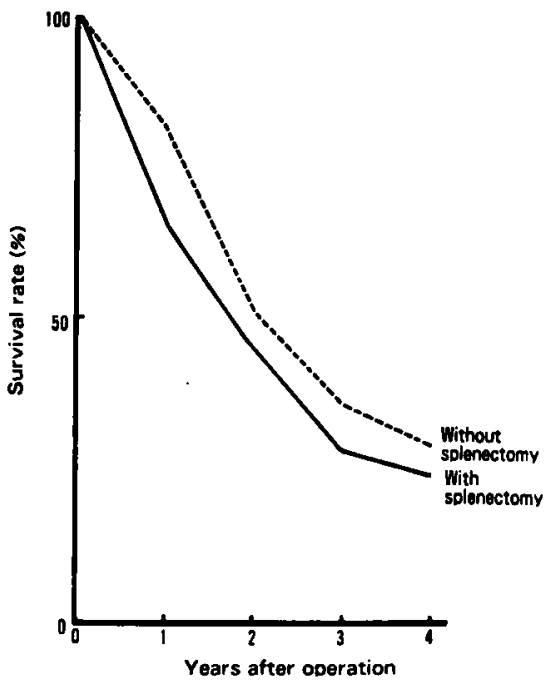

图4 stage III胃渵例の揞脾の有無と生存率

\section{4) stage IV筩蛇例の生存率}

stage IV胃癌例の摘脾の有無による生存率をみた。 非摘脾群の術後 1，2，3，4年の生存率は各 $36.4 \%$, $18.2 \%, 9.1 \%$ ，摘脾群では各52.9\%，43.7\%，43.7\%， $27.8 \%$, stage III例とは逆に摘脾が生存率を上昇さ せた（图 6).

またそれに免疫療法の有無をからませてみると、非 摬脾群では，免疫療法を行わない例の術後 4 年までの 生存率は各 $50.0 \% ， 33.5 \% ， 33.5 \% ， 16.8 \%$ ，免疫㞠 法を併用すると各 $20.0 \% ， 0 \% ， 0 \% ， 0 \%$ ，摘脾 をしない時には免疫㞠法を行わない方が生存率が高 かった.摘脾群についてみると、兔疫療法を行わなかっ

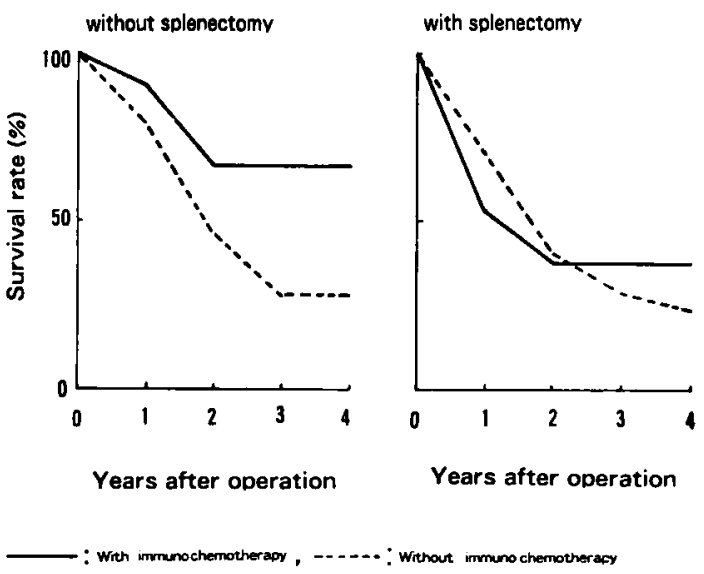

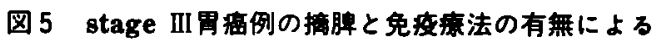
生存嗝

た例での生存率は各 $52.0 \%, 42.5 \%, 42.5 \%, 21.5 \%$ ， 免疫療法を行なった例では各53.8\%,35.9\%，35.9\%， $35.9 \%$ ，摘脾を行なった時には兔疫療法の有無で生 存率に大きな差がなかった（図７）。

\section{IV. 考 察}

免疫療法は Mathê $の$ acute lymphoblastic leukemia に対する BCG の著明な有効報告"以来急速な進 展をみせ，今や日常の治㞠の中に定着しかけていると いえよ5，しかし，兔疫㞠法す本来目標とされる特異 的免疫療法よりも免疫倵活剤を用いる非特異的免疫㞠 法が主体を占めているのが実情であり，免疫賦活剤の 投与方法についてまだ検討の余地が多く牫されてい る.

一方免疫療法, 特に免疫賦活剂を用いる非特異的免 


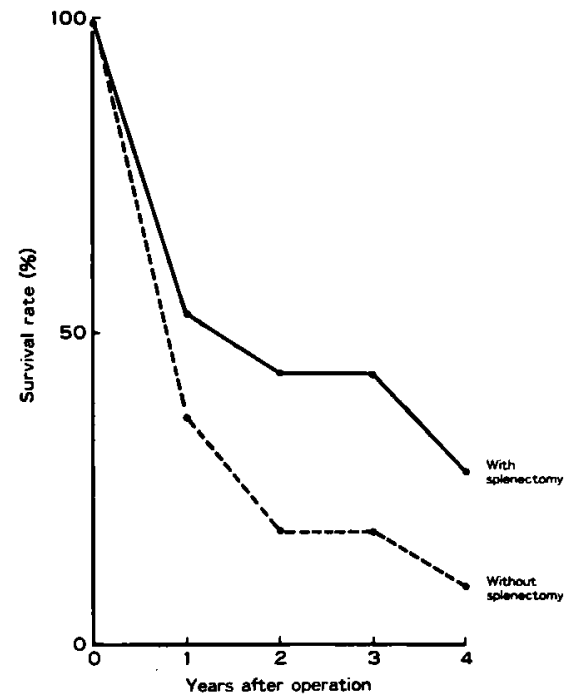

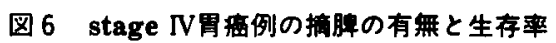

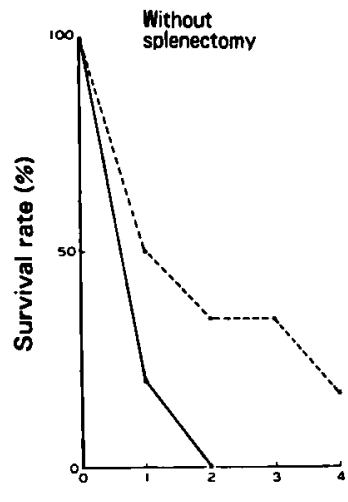

Years after operation

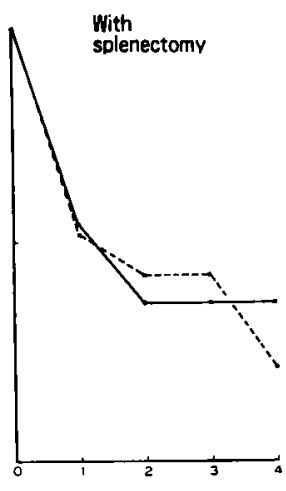

Years after operation
図 7 stage IV胃癌例の掊脾と免疫疾法の有無による 生存率

疫療法を行う際に, 免度抑制的に働く臟器であるとさ れる脾葴の有無は大きな問題であろう。

脾喴は T-cell B-cell の late maturationの場で あり，ADCCに関与する抗体や killer cell の産生に関

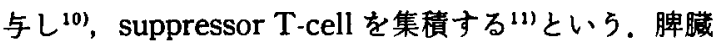
の液性免疫に与える影赖は，種々の免疫グロブリンを 分泌する抗体産生細胞により血清中の免疫クロブリ ン，特にIgM の増加をむたらすことである ${ }^{12)}$. 細胞性 免疫能に与える脾缄の役割はまだ明確ではないが，in vitroにおけるリンパ球混合培羔反応に影響をるたら さずリンバ節細胞の羊赤血球に対する in vitro, in vivoでの反応に影敕を与えず，同種皮庙移植での拒否 反応に影響を与えないことなどが分っている(13)ー15).こ のよ5に非癌での摘脾は末梢血の T-cell 数を減少, T. cell の mitogen に対する反応を低下させ, B-cell 数を 増加させる ${ }^{16)}$.

担癌生体において脾缄が免疫抑制的に濑いているこ とが知られている. Hellström ら》は，あらかじめ摘脾 したマウスにメチルコラントン (MC) 誘発肉尰を移植 した場合, 血清の blocking 活性の出現が抑制されてい ることをみており，岡田 ${ }^{31}$ ， Ehrlich 癌細胞 $5 \times 10^{8}$ 個 を移植する 7 日前または 5 日後に摘脾をするとマウス の所属リンパ節のマクロファーシ遊走阻止活性の增強 と腫煌の退縮，消失をみている。また Meyer ら フィッシャー系ラット10週龄に摘脾し， 3 週後に $3 \times$ $10^{6}$ 個の Ward 結腸癌細胞を皮下移植して, 摘脾マウス では非摘脾群に較べてリンハ節細胞の MLC反応の抑 制が防止され， suppressor 活性が抑制されて，生存日 数が著しく延長することをみている，また寺田ら は仡 MCA 肉腫を移植する 3 日前に摘脾しておくと延命が みられるとしている。畽湯細胞移植前の摘脾が抗畽場 効果をもたらす報告はこのようにかなりみられるが， 今回の成績の上 示したのは Yu ら 201 報告をみるにすぎない，彼らは Winnの assay を用いて担癌早期とともに末期の脾窚 にす免疫抑制作用が強く，摘脾が有効であろらことを 報告している。

臨床的には，われわれはすでに前期胃癌 stage I， II 例には摘脾が有効なることを報告したが211，上中部 胃癌では脾門部リンパ節が所属リンバ節であり，充分 なリンパ節郭清を行らためには摘脾を併用すべきこと が多い21). しかし結果的にはリンパ節転移の可能性の 高いあのに摘脾を行らことが多く，よって摘脾群の予 後が悪いかの印象が強かった。兔度学的ハラォーター で摘脾の影響をみると，われわれの成績では摘脾の奻 果のなかった stage III胃癌では摘脾群の細胞性免度能 は対照群と差がなかったが，摘脾が有効な stage IVて は摘脾群のハララメーターの值が対照群のそれより獄後 に増強した，生存率でみると，背景因子をそろえた今 回の検討では，進行胃癌 stage IVです摘脾が有奻と なった。このような報告は免疫学的観点より藤本ら が, 手術上の観点より武藤ら ${ }^{23)}$ が述へているが,われわ れの成績でも stage III胃癌では摘脾はむしろ逆奻果 で,今後への問題む多い.

摘脾と免疫㞠法との両方についてみると, 摘脾が焦 
奻な stage III胃癌では非摘脾群で免疫療法を行なった 例の生存率が高く，摘脾が有効であった stage IV胃澏 では非摘脾群で免疫療法を行わなかった例の生存率が 高かったといら今回の成績の解析はまた充分でなく， 今後，更に検討をすすめたい。

\section{考文献}

1）三埨恕昭，小野二三雄，守山 稔他：胃癌免疫化学 療法の効果の検討一術後 2 年問の経過追求一, 日 消外会誌，14：1294-1299，1981.

2）湯村正保，林茂夫，岡田 剛他：癌免疫療法. (2) 腪合併切除を併用した癌免度㞠法の可能性につい $\tau$ ， 日外会誌， $76 ： 1076-1078 ， 1975$.

3）岡田 剛：摘脾の董掦增殖と細胞性免疫能に及ほ す影暂に関する実験的研究，岡山医会誌，92： 39-51, 1980 .

4）胃癌研究会：外科・病理. 胃癌取り扱い規䄪, 金原 出版, 1979.

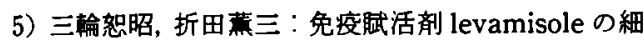
胞性免疫能賦活効果, 日癌治会誌, 16 ： 1231-1238, 1981.

6）三陯㤎昭，折田萧三：リン八球幼若化率による消 化器癌患者免疫能の長期梌索, 臨床外科, 32 ： 891-896, 1977.

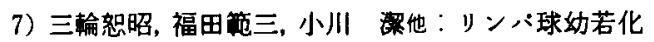
率，シベルクリン反応，DNCB 反応による癌進行 度の判定，外科， $36: 477-482 ， 1975$.

8）螺良英郎，久野梧郎，曾根三郎地：癌免度化学療法 における皮庙反応，癌の免疫化学意法一基礎と臨 床一, 井口染，服部孝雄編，南山堂, p. 14-25, 1980.

9) Mathé, G., Amiel, J.L., Schmarzenberg, L., et al.: Active immunotherapy for acute lymphoblastic leukemia. Lancet, 1: 697-699, 1969.

10) Weissman, I., Lannin, D., Jerabek, L., et al.: Cellular immunity to heterologous erythrocytes in vitro. I. The role of surface-adherent cells and specific mediators in an effector mechanism. Cell. Immunol., 7 : 222-236, 1973.

11) Slavin, S. and Strober, S.: Induction of allograft of tolelance after total lymphoid irradiation (TLI) : Development of suppressor cells of the mixed lymphocyte reaction (MLR). J. Immunol., 123 : 942-946, 1979.

12) Wortis, H.H., Dressor, D.W. and Anderson, H. P. : Antibody production studied by means of the localized haemolysis in Gel (LHG) assay. Immunology, 17 : 93-110, 1969.

13) Kubai, L. and Auerbach, R. : Neonatal splenectomy: Abscence of runting in mice. Nature (London), $217: 360,1968$.

14) Hood', J.K. and Reed, N.D. : Neonatal splenectomy and survival in mice. Nature (London), $217:$ 1056-1057, 1968.

15) Claret, I., Morales, L. and Montaner, A.: Immunological studies in the postsplenectomy syndrome. J. Pediat. Surg., 10 : 59-64, 1975.

16) Slavin, S., Zan-Bar, I. and Strober, S.: Long term effect of splenectomy on immunocompetent cells of adult mice. Cell. Immunol., 55 : 444 $-455,1980$.

17) Hellström I., Hellström, K.E. and Sjögren, H. : Serum mediated inhibition cellular immunity to methylcholanthrene-induced murine sarcomas. Cell. Immunol., $1: 18-30,1970$.

18) Meyer, J., Argyris, B.F., Meyer, J.A., et al. : Splenectomy, suppressor cell activity, and survival in tumor bearing rats. J. Surg. Res., 29 : 527-532, 1980.

19）寺田信国，松本志志，園山輝久他：脾剔の担癌生体 に及ぼす影䡴に関する研究. 第81回日外総会記事, p. 339, 1981.

20) Yu, S., Lannin, D.R., Tsui-Collins, A.L., et al.: Effect of cyclophosphamide on mice bearing methylcholanthrene induced fibrosarcoma. Cancer Res., $40: 2756-2761,1980$.

21）大橋一郎，高木国夫，太田博拨他：進行胃癌におけ る䐙脾合併切除の意義一とくにリン八: 節転移につ いて一， 日外会誌，12：993-999，1979.

22）藤本 茂，高㛢 諴，南 智他：進行胃癌に批 る脾合併切除の検討一とくに免疫学的検討, 日消 外会誌, $12 ： 976-982,1979$.

23）武藤烸一，川口正樹，田中乙雄他：合併脾摘の遥 応，第18回日消外総会記事，p. 758，1981。 